\title{
Investigation of The Effects of Silymarin on Valproic Acid-induced Kidney Damage in Rats
}

\author{
Ibrahim AKTAŞ ${ }^{1, a, *}$, Dilek BAYRAM ${ }^{2, b}$ \\ ${ }^{1}$ School of Health Services, Department of Pharmacology, Adiyaman University, Adiyaman, Turkey \\ ${ }^{2}$ Faculty of Medicine, Department of Histology and Embryology, Süleyman Demirel University, Isparta, Turkey \\ aORCID: 0000-0002-0956-8204, bORCID:0000 000335682673
}

\begin{abstract}
Geliş Tarihi: 19.02.2020
Kabul Tarihi: 17.06.2020

Abstract: In this study; we aimed to investigate the protective effects of silymarin (SLY) against kidney damage on valproic acid (VPA)-induced rats using histological and biochemical evaluations. Experimental procedures were performed on 21 male Sprague Dawley rats. Rats were divided randomly into three groups: group 1, control; group 2, VPA; group 3, VPA+SLY. The control group was given $1 \mathrm{~mL} 0.9 \% \mathrm{NaCl}$ orally for 14 days. The VPA group was given $500 \mathrm{mg} / \mathrm{kg} /$ day VPA per os for 14 days. The VPA+SLY group was given $500 \mathrm{mg} / \mathrm{kg} / \mathrm{day}$ VPA and $100 \mathrm{mg} / \mathrm{kg} / \mathrm{day}$ SLY per os for 14 days. SLY treatment decreased the levels of creatinine $(\mathrm{Cr})$ and blood urea nitrogen (BUN) levels significantly $(p<0.05)$. In addition, increased amount of thiobarbitüric acid reactive substance (TBARS) and decreased levels of glutathione (GSH) with VPA were significantly suppressed by SLY in kidney tissue $(p<0.05)$. Histologically, the extent of kidney damage was remarkably lower in the VPA+SLY group $(p<0.005)$. In addition, VPA+SLY group had decreased oxidative stress, increased antioxidant activity and decreased histopathological changes compared to VPA group. This study revealed that the kidney damage induced by VPA was attenuated with SLY administration. SLY can protect rat kidney against VPA induced damage via anti-oxidative effect and might be useful for reducing the severity of kidney injuries.
\end{abstract}

Keywords: Valproic acid, Silymarin, Kidney damage, Rat

\section{Sıçanlarda Valproik Asitin İndüklediği Böbrek Hasarı Üzerine Silimarinin Etkileri}

Özet: Bu çalışmada, sıçan böbrek dokusunda valproik asit (VPA) kaynaklı hasara karşı silimarinin (SLY) koruyucu etkilerinin histolojik ve biyokimyasal değerlendirmeler kullanılarak araştırılması amaçlandı. Deneysel işlemler, 21 adet Sprague Dawley sıçanı üzerinde gerçekleştirildi. Sıçanlar rastgele üç eşit gruba ayrıldı: grup 1, kontrol; grup 2, VPA; grup 3, VPA+SLY. Kontrol

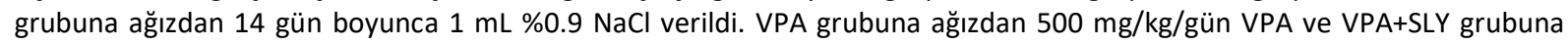
ağızdan $500 \mathrm{mg} / \mathrm{kg} / \mathrm{gün}$ VPA ve $100 \mathrm{mg} / \mathrm{kg} / \mathrm{gün}$ SLY 14 gün süre ile uygulandı. SLY tedavisi ile kreatinin (Cr) ve kan üre azotu (BUN) seviyeleri anlamlı derecede düştü $(p<0.05)$. Ek olarak, böbrek dokusunda VPA ile artan tiyobarbitürik asit reaktif madde (TBARS) seviyesi ve azalan glutatyon (GSH) seviyesi, SLY tarafından önemli ölçüde baskılandı $(p<0.05)$. Histolojik inceleme sonucu, VPA+SLY grubunda böbrek hasarının derecesi anlamlı olarak düşük bulundu ( $p<0.005)$. VPA+SLY grubunda; VPA grubuna göre oksidatif stres ve histopatolojik değişikliklerde azalma tespit edildi. Bu çalışma ile VPA'nın indüklediği böbrek hasarının SLY uygulaması ile azaldığı ortaya konuldu. SLY, sıçan böbreğinde VPA kaynaklı hasara karşı anti-oksidan etkisi böbreği koruyabilir ve böbrek hasarının boyutunu azaltmak için faydalı olabilir.

Anahtar Kelimeler: Valproik asit, Silimarin, Böbrek hasarı, Sıçan

\section{Introduction}

In general, valproic acid (VPA) is routinely used to treat certain types of epilepsy seizures in children and adults (Emekli-Alturfan et al., 2015). It inhibits the disintegration of $\gamma$-aminobutirik acid (GABA) in synapses and increases its concentration in the environment, generating an antiepileptic effect (Dökmeci and Dökmeci, 2016). It also increases dopamine and serotonin levels. Therefore, it can be used in the treatment of diseases such as melancholy, brain tumor, generalized epilepsy, bipolar mania, psychiatric disorders and migraine (Ahangar et al., 2017; Heidari et al., 2018; Kudin et al., 2017; Semmler et al., 2017). Significant side effects have been reported with long-term use of VPA and some of them are; pancreatitis, elevated liver enzymes, hepatitis, and bone marrow suppression. Among the earliest symptoms of VPA toxicity are anorexia, nausea, vomiting and gastralgia (Dökmeci and Dökmeci, 2016; EmekliAlturfan et al., 2015). Production of reactive oxygen species (ROS) occurs with VPA application. It can directly damage cellular molecules such as proteins, lipids and DNA, and alter signal paths through the activation of redox-sensitive transcription factors. VPA treatment has been associated with oxidative stress in a number of studies in both human and animal models, particularly in the kidneys, causing serious damage to cells, necrosis and atrophy (Emekli-Alturfan et al., 2015; Goli et al., 2019; Heidari et al., 2018). VPA causes renal ROS, depletes 
glutathione (GSH) reservoirs, reduces tissue antioxidant capacity; thiobarbitüric acid reactive substance (TBARS) and other lipid peroxidation products increase the amount (Heidari et al., 2018). Vegetable ingredients containing enzymatic and non-enzymatic antioxidant mechanisms are required for the detoxification of ROS formed by VPA (Emekli-Alturfan et al., 2015).

Silymarin (SLY) is an extract from a milk thistle (Silybum marianum) plant. It also has antiinflammatory, anti-apoptotic and antioxidant properties. SLY is mainly used in the treatment of kidney injuries such as alloxan-induced diabetes mellitus, renal ischemia-reperfusion injury and drug-induced toxicity (Goli et al., 2019; Hassan et al., 2017). In this case, SLY binds to receptors in renal cell membranes and prevents toxins from binding in these regions, thereby reducing druginduced renal cellular damage (Kyriakopoulos et al., 2018). The protective effect of SLY is that it acts as a powerful antioxidant and neutralizes harmful free radicals resulting from the breakdown of toxic substances. In addition, SLY, by concentrating in kidney cells and ribonucleic acid polymerase enzyme regulation by increasing protein synthesis in the ribosome is to help repair and regeneration (Hassan et al., 2017; Li et al., 2017; Rafieian-Kopaie et al., 2012).

In this research, we aimed to investigate the possible renal protective effect of SLY against VPAinduced renal damage in rats.

\section{Materials and Methods}

Chemicals: VPA and SLY were purchased from Liba Co (Turkey) and Madaus (Turkey), respectively. VPA and SLY doses were determined based on previous studies (Beydilli et al., 2015; Graf et al., 1998). Hydrochloric acid ( $\mathrm{HCl})$, trichloroacetic acid (TCA), thiobarbuturic acid (TBA) and paraffin were obtained from, Sigma-Aldrich (Germany). Xylene, hematoxylin-eosin and ethanol were obtained from Merck (Germany). All other chemicals were the best analytical grade and were purchased from SigmaAldrich (USA).

Animals: In this study, 21 male SpragueDawley rats (210-250 g, for 8 weeks) were used. The study was carried out according to the protocol approved by the Experimental Animal Ethics Committee of Firat University (Protocol 2019/07). The rats were housed in a $12 \mathrm{~h}$ dark: $12 \mathrm{~h}$ light cycle at $21^{\circ} \mathrm{C}$ with free access to water and feed.

Treatment Protocol: Animals were randomised into three groups, with seven rats in each group, as follows: Control, VPA and VPA+SLY. The control group was given $1 \mathrm{~mL} 0.9 \% \mathrm{NaCl}$ orally for 14 days. The VPA group was given $500 \mathrm{mg} / \mathrm{kg} /$ day VPA per os for 14 days (Tong et al., 1967). The VPA+SLY group was given $500 \mathrm{mg} / \mathrm{kg} /$ day VPA and 100 $\mathrm{mg} / \mathrm{kg} /$ day SLY per os for 14 days (Beydilli et al., 2015). Body weights were determined at the beginning and the end of the study. Rats were euthanized by cervical dislocation under diethyl ether anesthesia at the end of the 14th day. The entire kidneys were excised and weighed, and were placed in formalin for histopathological analysis. In tissues with oxidative stress parameters, TBARS and GSH were preserved at $-86{ }^{\circ} \mathrm{C}$ until analysis. Blood samples were collected from jugular veins, centrifuged for 5 minutes at $5,000 \times \mathrm{g}$, and biochemical analysis was performed on the serum.

Biochemical Evaluation: Kidney serum biomarkers including creatine $(\mathrm{Cr}) \mathrm{mg} / \mathrm{dL}$ was analyzed with the Olympus 2700 analyzer (Olympus Diagnostica $\mathrm{GmbH}$, Germany). In addition, blood urea nitrogen (BUN) $\mathrm{mg} / \mathrm{dL}$ levels were evaluated according to Reitman-Frankel colorimetric transaminase procedure (Crowley, 1967).

Oxidative Stress Biomarkers: TBARS measurements were conducted in the kidney tissue (Casini et al., 1986). Two volumes of sample and two volumes of stock solution $10.375 \%$ thiobarbituric acid in $0.25 \mathrm{~N} \mathrm{HCl}$ and $15 \%$ trichloroacetic acid) were mixed in a centrifuge tube. The solution was heated for 15 minutes in boiling water and then cooled. The solution was centrifuged at $5.000 \mathrm{~g}$ for 10 minutes to separate. Then the test samples were read at $532 \mathrm{~nm}$ on the spectrometer. This formula was used in the calculation $(356,1 \times$ adsorbent value $=$ result $\mathrm{nmol} / \mathrm{gr}$ (nonomol/g)) (Placer et al., 1966).

Glutathione (GSH) levels in raw kidney tissues were measured according to Sedlak and Lindsay (1968) method (Sedlak and Lindsay, 1968). Samples were precipitated with 50\% TCA and centrifuged at $1000 \times \mathrm{g}$ for 5 minutes. In the supernatant of the precipitated sample, $0.5 \mathrm{~mL}$ was receipted, and 2 $\mathrm{mL}$ of Tris-EDTA buffer $(0.2 \mathrm{M}, \mathrm{pH}=8.9)$ and $0.1 \mathrm{~mL}$ of $0.01 \mathrm{M}$ 5.5'-dithio-bis-nitrobenzoic acid were added. The mixture was allowed to stand at room temperature for 5 minutes and its adsorbance was measured at $412 \mathrm{~nm}$ on the spectrometer. This formula was used in the calculation (961 x adsorbent value $=$ result $\mu \mathrm{mol} / \mathrm{g}$ ). In these two experimental studies Perkin Elmer Precisely, Lambda 25, UV/VIS spectrometer.

Histopathological Examinations: The kidney tissues taken from animals were fixed in $10 \%$ neutral formalin solution. After fixation, tissues 
were washed overnight in running water. These washed samples were dehydrated with ethanol, cleared with xylene and embedded in paraffin. 4-5 $\mu \mathrm{m}$ thick sections were taken from the paraffin blocks with a rotary microtome (RM2125RTS, Leica, Germany). The samples from all groups were stained with hematoxylin \& eosin for histopathological evaluation. Modified semiquantitative scale were used for the evaluation of histopathological changes; [(0): none, (1): mild, (2): moderate, (3): severe grade] (Refaiye et al., 2011). Samples were evaluated and visualized with imaging-assisted binocular light microscopy (ECLIPSE Ni-U, Nikon, and Tokyo, Japan).

Statistical Analyze: SPSS version 20.0 was used for statistical analysis. Shapiro-Wilk test was used to evaluate normality. One-way ANOVA and post-hoc,
LSD were applied for in-group comparisons of parametric data; Kruskal Wallis test was used for non-parametric biochemical data. The same test was also used for semi-qualified evaluation of histopathological scores and for differences in the data measured between the groups. Mann-Whitney $U$ test was used to compare the two groups. Data were considered statistically significant for $p \leq 0.05$.

\section{Results}

Biochemical Evaluation: $\mathrm{Cr}$ and BUN levels were significantly increased in VPA group compared to control group and VPA + SLY group $(p<0.03)$. SLY treatment resulted in a significant decrease in VPAinduced $\mathrm{Cr}$ and BUN levels in VPA + SLY group compared to VPA group $(p<0.04)$ (Table 1$)$.

Table 1. Serum biochemical and kidney tissue oxidative stress biomarkers of the experimental groups.

\begin{tabular}{llll}
\hline & Control & VPA & VPA + SLY \\
\hline Serum biochemical biomarkers & & & \\
Cr (mg/dL) & $0.48 \pm 0.07^{\mathrm{b}}$ & $0.56 \pm 0.02^{\mathrm{a}, \mathrm{c}}$ & $0.46 \pm 0.014^{\mathrm{b}}$ \\
BUN (mg/dL) & $54.71 \pm 1.18^{\mathrm{b}}$ & $62.42 \pm 0.94^{\mathrm{a}}$ & $53.16 \pm 1.13^{\mathrm{b}}$ \\
Tissue oxidative stress biomarkers & & & \\
GSH ( $\mu$ mole/gr tissue) & $0.265 \pm 0.004^{\mathrm{b}}$ & $0.222 \pm 0.003^{\mathrm{a}, \mathrm{c}}$ & $0.251 \pm 0.007^{\mathrm{b}}$ \\
TBARS (nmole/gr tissue) & $0.129 \pm 0.011^{\mathrm{b}}$ & $0.194 \pm 0.007^{\mathrm{a}, \mathrm{c}}$ & $0.134 \pm 0.011^{\mathrm{b}}$ \\
\hline
\end{tabular}

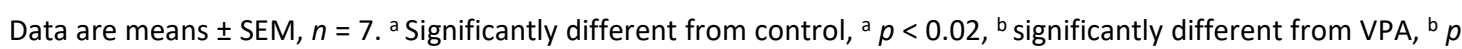
$<0.04,{ }^{c}$ significantly different from VPA + SLY, ${ }^{c} p<0.05$. VPA, valproic acid; SLY, slymarin; GSH, glutathione; TBARS, thiobarbituric acid reactive substances; $\mathrm{Cr}$, creatinine and $\mathrm{BUN}$, blood urea nitrogen.

Table 2. Histopathological scoring of kidney sections of experimental groups.

\begin{tabular}{llll}
\hline Parameters/scores & Control & VPA & VPA+SLY \\
\hline Dilation of Proximal Distal Tubules & - & $+++^{a}$ & $+^{\mathrm{a}}$ \\
Glomerular Degeneration & - & $+++^{\mathrm{a}}$ & $++{ }^{\mathrm{b}}$ \\
Vascular Congestion & - & $+++^{\mathrm{a}}$ & $++^{\mathrm{b}}$ \\
Hemorrhagic Areas & - & $+++^{\mathrm{a}}$ & $++^{\mathrm{b}}$ \\
Mononuclear Cell Infiltrations & - & $+++^{\mathrm{a}}$ & $++{ }^{\mathrm{b}}$ \\
Tubular Dilatation in Medulla & - & $+++^{\mathrm{a}}$ & $++^{\mathrm{b}}$ \\
Degeneration of Proximal Distal Tubules & - & $+++^{\mathrm{a}}$ & $++{ }^{\mathrm{b}}$ \\
\hline
\end{tabular}

Scoring as described in the methods section. $n=7$. VPA, valproic acid; SLY, slymarin; a VPA increased kidney damage, $p<0.05$ vs. control group. ${ }^{b}$ SLY reduced kidney damage, $p<0.05$ vs. VPA group.

Oxidative Stress Biomarkers: The results in Table 1 showed a significantly higher level of TBARS $(p<0.03)$ and significantly lower levels of GSH $(p<$ 0.03 ) in the VPA group. SLY treatment resulted in a significant decrease in VPA-induced TBARS level $(p<$ $0.04)$ and a significant increase in VPA-reduced GSH level $(p<0.04)$ in VPA+SLY group compared to VPA group. 

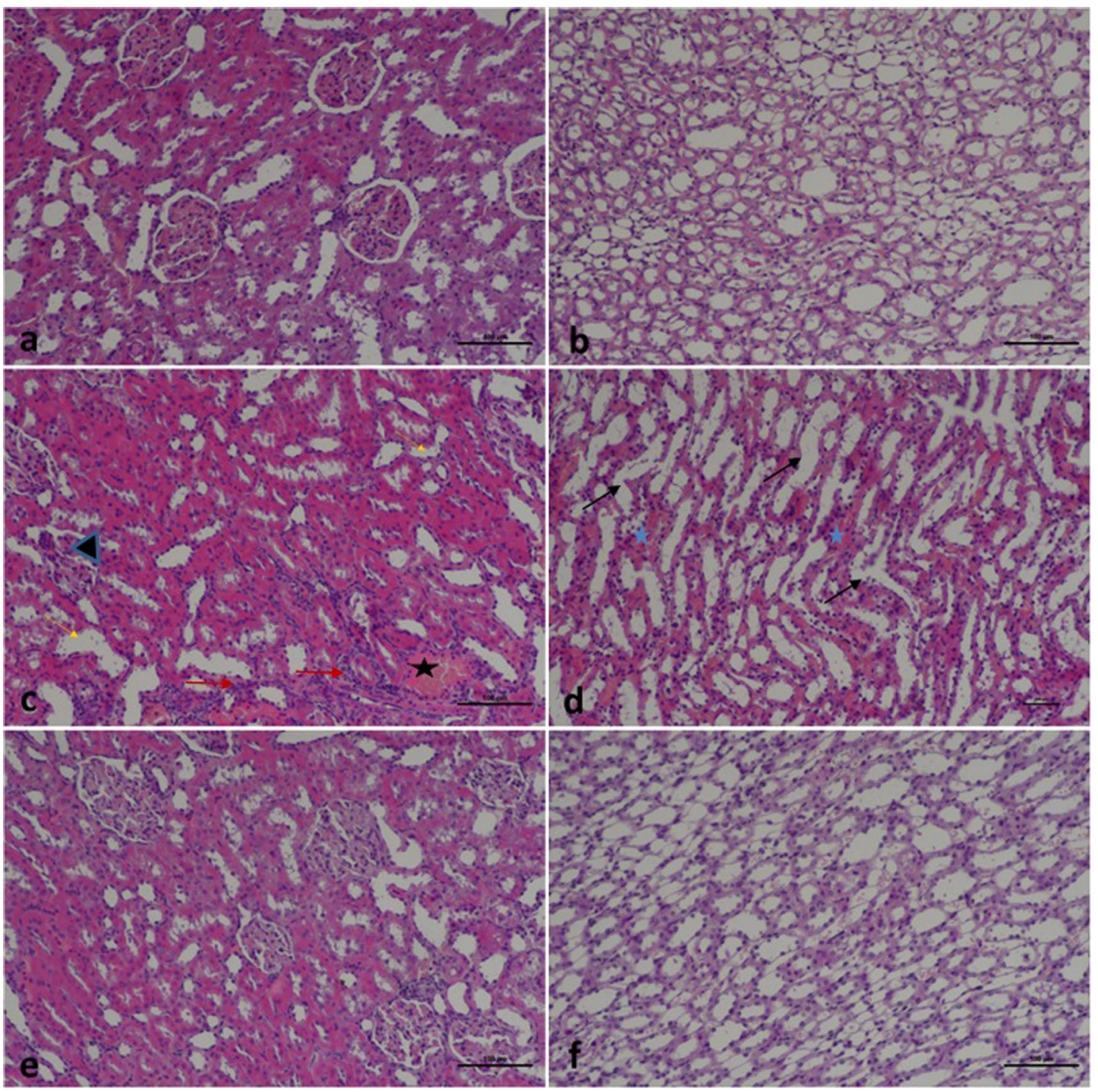

Figure 1. Rat kidney tissue section. a-b; control group; normal histological appearance is observed in kidney tissue sections (a; cortex; bowman capsule, distal, proximal tubules b; medulla; collecting tubules), (H-E, x20). c-d; VPA given to the group; kidney tissue sections: $c$ (cortex), d (medulla); red arrows; mononuclear cell infiltrations; yellow arrows; blue star shows hemorrhagic areas in the medulla (c-d; $\mathrm{H}-$ $\mathrm{E}, \mathrm{x} 20$ ); VPA+SLY given group; Kidney tissue sections, e (cortex) and $\mathrm{f}$ (medulla) compared to VPA group and cortex and significant improvement in the medulla (e-f; $H-E, \times 20)$. Showed decrease of histopathological findings compared to VPA group.

Histopathological Results: The histological examination of the kidney tissue sections of the control group showed no difference from the normal histological structures (Figure 1: $a-b$, Table 2). When the kidney tissues of the VPA group were examined, significant histopathological changes were observed compared to the control group ( $p<$ $0.05)$. These changes; dilatation and degeneration of the proximal distal tubules, glomerular degeneration, vascular congestion, hemorrhagic areas, tubular dilatation of the medulla and mononuclear cell infiltrations (Figure 1: c-d, Table 2). In the VPA+SLY group, a significant improvement was observed in histopathological findings compared to the VPA group $(p<0.05)$ (Figure 1: e-f, Table 2).

\section{Discussion and Conclusions}

Long-term use of VPA for the treatment of epilepsy has been reported to cause many side effects in the liver, kidneys, pancreas, central nervous system and hemopoietic system (Belcastro et al., 2013). The kidney is an important organ that plays a role in blood filtration in the body. Among its main duties are; removing waste products, balancing electrolytes in the body, controlling blood pressure, stimulating the production of red blood cells, regulating water balance and maintaining acid-base balance in the blood. The drugs and metabolites that fill the treatment process in the body are excreted in the urine by the kidneys. Therefore, the use of drugs other than the treatment dose may cause damage to the kidneys 
(Nerdy and Ritarwan, 2019). Although VPA is relatively a safe drug, it can cause serious side effects on the biological system when used at higher concentrations and for extended periods of time (Chaudhary et al., 2017).

Oxidative stress is the shift of the balance between ROS and antioxidants formed as a result of toxicity in the body to the ROS side. TBARS resulted from ROS is a product of lipid peroxidation, an important indicator of oxidative stress (Shoji and Koletzko, 2007). It also plays an important role in the pathogenesis of DNA. The level of oxidative stress occurring in the body is tolerated by enzymatic and non-enzymatic antioxidant systems. GSH is a non-enzymatic antioxidant (Arora and Singh, 2014; Roshan and Stanton, 2013; Xu et al., 2005). Oxidative stress caused by VPA application is considered as one of the factors leading to kidney dysfunction (Hassan et al., 2017b). Results; the increase in ROS levels increased tissue lipid peroxidation (TBARS) and decreased antioxidant activity (GSH) (de Avelar et al., 2017; Heidari et al., 2018; Placer et al., 1966). According to the hypothesis announced by the researchers, SLY reduces lipid peroxidation due to its antioxidant properties and increases endogenous concentrations of antioxidant enzymes such as GSH, thereby reducing nephropathy by preventing cellular damage (Goli et al., 2019; Zheng et al., 2014). In addition, SLY sweeps up the free radicals and prevents lipid peroxidation, thereby reducing the damage to the cells and fixing the cell membrane (Shereen et al., 2013).

With the breakdown of protein during digestion, ammonia is formed and reaches the liver through blood. Here, ammonia turns into BUN, which is less dangerous for the body. BUN, which comes to the kidneys through the blood, is drained out of the body through urine by filtering here (Bilgic, 2020). Cr; It is formed during the daily movement of muscles and is a natural waste product in the body. This product is found in the body, blood and urine. Then it is excreted from the body with the help of kidneys. The blood must be as clean as possible for the body to function optimally. A high level of $\mathrm{Cr}$ in the blood puts a person at risk for potentially life-threatening kidney disorders such as uremia (Oh and Briefel, 2017). BUN and $\mathrm{Cr}$ are metabolic waste products that are excreted in the urine by the kidneys, and only a small amount remains in the blood. Since serum levels cannot be excreted in the urine, it increases in kidney degeneration. For example; chronic hypertension, diabetes, kidney stones, kidney inflammation, kidney infection, dehydration (Speir et al., 2015). This accumulated toxic substance causes tubular cell damage by changing the permeability of kidney cells and causing cellular destruction (Hassan et al., 2017b). The chemical structure of VPA contains an eight-carbon fatty acid called propyl acetate. This structure interacts with the cell membrane, causing toxic effects. As an indicator of this toxicity in the cell membrane, it causes an increase in by-products such as BUN and Cr (Ibrahim et al., 2017). In our study, serum $\mathrm{Cr}$ and BUN levels increased as a biochemical evidence of kidney damage in VPA treatment. The results we obtained in the present study are consistent with the literature (de Avelar et al., 2017; Heidari et al., 2018). SLY therapy; showed regenerative properties of damaged kidney cells. In addition, it decreased $\mathrm{Cr}$ and BUN levels closer to the control group (Güzel et al., 2019). Our study is compatible with the literature information (Goli et al., 2019).

In this study, VPA showed significant histological changes in the kidneys. In the histological examination of the VPA group; dilatation and degeneration in proximal and distal tubules, glomerular degeneration, vascular congestion, hemorrhagic regions, mononuclear cell infiltrations in the cortex, tubular dilation and degeneration, hemorrhagic regions in the medulla were observed (Figure 1: c-d, Table 2). These degenerative findings were also found in the SLYtreated group, but were less severe than the VPA group (Figure 1: e-f, Table 2). In the study of Heidari et al. (2018), animals treated with VPA $(500 \mathrm{mg} / \mathrm{kg}$ ) for 14 days showed interstitial nephritis, fibrosis and tissue necrosis in the kidney (Heidari et al., 2018). SLY increases the regeneration of renal tubular cells, provides membrane stabilization and improves kidney tissue damage (Li et al., 2017). In addition, SLY increased the endogenous antioxidant defense system, reduced VPA-induced cellular damage and retained histological structure (Hassan et al., 2017a; Kandimalla et al., 2017). In another study, Goli et al. (2019) reduced degenerative and necrotic changes of SLY were observed in rats with diabetes mellitus. Its mechanism may be to reduce proteinuria and weaken diabetic kidney damage due to its antioxidant function (Goli et al., 2019).

In conclusion, the results of the present study showed that SLY improved the biochemical, histological and structural changes of VPA-induced kidney damage in rats. In addition, mechanisms of these effects may include inhibition of lipid peroxidation and protection of antioxidant enzymes. Because of its antioxidant activity, SLY may protect kidney against the damage caused by VPA. However, further studies should be conduct to determine the mechanisms of underlying the therapeutic effects of SLY. 


\section{References}

Ahangar N, Naderi M, Noroozi A, Ghasemi M, Zamani E, Shaki F, 2017: Zinc deficiency and oxidative stress involved in valproic acid induced hepatotoxicity: Protection by zinc and selenium supplementation. Biol Trace Elem Res, 179(1), 102-9.

Arora M, Singh UK, 2014: Oxidative Stress: Meeting Multiple Targets in Pathogenesis of Diabetic Nephropath. Curr Drug Targets, 15, 531-8.

Belcastro VD, Egidio C, Striano P, Verrotti A, 2013: Metabolic and endocrine effects of valproic acid chronic treatment. Epilepsy Res, 107(1-2), 1-8.

Beydilli H, Yilmaz N, Cetin ES, Topal Y, Celik O, Sahin C, Topal H, Cigerci IH, Sozen H, 2015: Evaluation of the protective effect of silibinin against diazinon induced hepatotoxicity and free-radical damage in rat liver. Iran Red Crescent Med J, 17(4), 1-7.

Bilgiç MA, 2020 BUN nedir? Medikal Park. https://www.medicalpark.com.tr/bun/hg-2186, Erişim tarihi; 09.06.2020.

Casini AF, Ferrali M, Pompella A, Maellaro E, Comporti M, 1986: Lipid peroxidation and cellular damage in extrahepatic tissues of bromobenzene-intoxicated mice. Am J Pathol, 123(3), 520-31.

Chaudhary S, Ganjoo P, Raiusddin S, Parvez S, 2015: Nephroprotective activities of quercetin with potential relevance to oxidative stress induced by valproic acid. Protoplasma, 252(1), 209-17.

Crowley LV, 1967: The Reitman-Frankel colorimetric transaminase procedure in suspected myocardial infarction. Clin Chem, 13(6), 1-7.

de Avelar CR, Pereira EM, de Farias Costa PR, de Jesus RP, de Oliveira LPM, 2017: Effect of silymarin on biochemical indicators in patients with liver disease: Systematic review with meta-analysis. World J Gastroenterol, 23(27), 5004-17.

Dökmeci İ, Dökmeci AH, 2016: Sağlık Yüksek Okulları İçin Farmakoloji. 2. Baskı, İstanbul Tıp Kitapevi, İstanbul, Türkiye.

Emekli-Alturfan E, Alev B, Tunali S, Oktay S, Tunali-Akbay T, Ozturk LK, Yanardag R, Yarat A, 2015: Effects of edaravone on cardiac damage in valproic acid induced toxicity. Ann Clin Lab Sci, 45(2), 166-72.

Goli F, Karimi J, Khodadadi I, Tayebinia H, Kheiripour N, Hashemnia M, Rahimi R, 2019: Silymarin attenuates ELMO-1 and KIM-1 expression and oxidative stress in the kidney of rats with type 2 diabetes. Indian J Clin Biochem, 34(2), 172-9.

Graf W, Oleinik O, Glauser T, Maertens P, Eder D, Pippenger C, 1998: Altered antioxidant enzyme activities in children with a serious adverse experience related to valproic acid therapy. Neuropediatrics, 29 (4), 195-201.

Guzel S, Sahinogullari ZU, Canacankatan N, Antmen SE, Kibar D, Coskun Yilmaz B, 2019: Potential renoprotective effects of silymarin against vancomycin-induced nephrotoxicity in rats. Drug Chem Toxicol, 1-7.

Hassan SMS, Youakim MF, Rizk AAE, Thomann C, Ahmad Z, 2017a: Does silybin protect against toxicity induced by polymyxin $E$ in rat kidney? Neurourol Urodyn, 36(5), 1278-87.
Hassan SS, Thomann C, Ettarh R, Ahmad Z, 2017b: Possible protective role of silybin against polymyxin E-induced toxic effect in rat kidneys: A biochemical approach. Neurourol Urodyn, 36(8), 2003-10.

Heidari R, Jafari F, Khodaei F, Shirazi Yeganeh B, Niknahad $H$, 2018: Mechanism of valproic acid-induced fanconi syndrome involves mitochondrial dysfunction and oxidative stress in rat kidney. Nephrology, 23(4), 351-61.

Ibrahim MA, Abdel-Karim RI, Tamam HG, Mohamed AA, Wani FA, 2017: Protective effect of silymarin and ascorbic acid in valproic acid-induced hepatic toxicity in male albino Rats. Mansoura J Forens Med Clin Toxicol, .25( 2), 33-49.

Kandimalla R, Dash S, Bhowal AC, Kalita S, Talukdar NC, Kundu S, Kotoky J, 2017: Glycogen-gold nanohybrid escalates the potency of silymarin. Int J Nanomedicine, 12, 7025-38.

Kudin AP, Mawasi H, Eisenkraft A, Elger CE, Bialer M, Kunz WS, 2017: Mitochondrial liver toxicity of valproic acid and its acid derivatives is related to inhibition of a-lipoamide dehydrogenase. Int J Mol Sci, 18(9), 111.

Kyriakopoulos G, Tsaroucha AK, Valsami G, Lambropoulou M, Kostomitsopoulos N, Christodoulou E, Kakazanis Z, Anagnostopoulos C, Tsalikidis C, Simopoulos CE, 2018: Silibinin improves TNF- $\alpha$ and M30 expression and histological parameters in rat kidneys after hepatic ischemia/reperfusion. J Investig Surg, 31(3), 201-9.

Li Y, Ye Z, Lai W, Rao J, Huang W, Zhang X, Yao Z, Lou T, 2017: Activation of sirtuin 3 by silybin attenuates mitochondrial dysfunction in cisplatin-induced acute kidney injury. Front Pharmacol, 8, 1-12.

Nerdy N, Ritarwan K, 2019: Hepatoprotective activity and nephroprotective activity of peel extract from three varieties of the passion fruit (Passiflora Sp.) in the albino rat. Open access Maced J Med Sci, 7(4), 53642.

Oh MS, Briefel G, 2017: Evaluation of renal function, water, electrolytes, and acid-base balance. 23rd ed, Elsevier, St Louis, USA.

Placer ZA, Cushman LL, Johnson BC, 1966: Estimation of product of lipid peroxidation (malonyl dialdehyde) in biochemical systems. Anal Biochem, 16(2), 359-64.

Rafieian-Kopaie M, Nasri H, 2012: Silymarin and diabetic nephropathy. J Renal Inj Prev, 1(1), 3-5.

Refaiy A, Muhammad E, ElGanainy EO, 2011: Semiquantitative smoothelin expression in detection of muscle invasion in transurethral resection and cystectomy specimens in cases of urinary bladder carcinoma. African J Urol, 17(1), 610.

Roshan B, Stanton R,. 2013: A story of microalbuminuria and diabetic nephropathy. J Nephropathol, 2, 234240.

Sedlak J, Lindsay RH, 1968: Estimation of total, proteinbound, and nonprotein sulfhydryl groups in tissue with Ellman's reagent. Anal Biochem, 25(1), 192205.

Semmler A, Frisch C, Bleul C, Smith D, Bigler L, Prost JC, Blom H, Linnebank M, 2017: Intrauterine valproate exposure is associated with alterations in 
hippocampal cell numbers and folate metabolism in a rat model of valproate teratogenicity. Seizure, 46, 7-12.

Shoji H, Koletzko B, 2007: Oxidative stress and antioxidant protection in the perinatal period. Curr Opin Clin Nutr Metab Care, 10, 324-8.

Shereen AE,; Manar HA,; Taiseer RI, 2013: Influence of Silymarin on Valproic Acid Induced Hepatotoxicity in Adult Male Albino Rats. Ain Shams J Forensic Med Clin Toxicol, 20, 221-32.

Speir RW, Stallings JD, Andrews JM, Gelnett MS, Brand TC, Salgar SK, 2015: Effects of valproic acid and dexamethasone administration on early bio-markers and gene expression profile in acute kidney ischemia-reperfusion injury in the rat. PLoS One, 10(5), 1-24.

Tong V, Teng XW, Chang TKH, Abbott FS, 2005: Valproic acid I: Time course of lipid peroxidation biomarkers, liver toxicity, and valproic acid metabolite levels in rats. Toxicol Sci, 86(2), 427-35.

Xu Y, Osborne BW, Stanton RC, 2005: Diabetes causes inhibition of glucose-6-phosphate dehydrogenase via activation of PKA, which contributes to oxidative stress in rat kidney cortex. Am J Physiol Renal Physiol, 289(5), 1040-7.

Zheng Q, Liu W, Liu Z, Zhao H, Han X, Zhao M, 2014: Valproic acid protects septic mice from renal injury by reducing the inflammatory response. J Surg Res, 192(1), 163-9.

*Correspondence author: ibrahim AKTAŞ

School of Health Services, Department of Pharmacology,

Adiyaman University, Adiyaman, Turkey

e.mail: iaktas@adiyaman.edu.tr 